\title{
Research on the Application of New Media in College Classroom Teaching of Business Administration
}

\author{
Liu Cailian \\ Wuhan Business University, Wuhan, 430056, China \\ email: 4586840@qq.com
}

\begin{abstract}
Keyword: New Media; Business Administration; College Classroom Teaching; Application Research
\end{abstract}

\begin{abstract}
Recent years have witnessed an increasing number of students majoring in business administration, which in turn accelerates the development of this major. Many problems, however, remain to be solved. With the coming of the information age, more importance has been attached to the application of information teaching technology to higher education in China. "New media" teaching has become an important form of daily teaching in colleges and universities. In this process, teaching activities and contents pay more attention to the enrichment of teaching contents, teaching forms and teaching interaction in more flexible ways, and attach more importance to innovative thinking. In order to keep pace with the times, business administration teaching can combine with new media to achieve effective innovation and transformation of teaching methods.
\end{abstract}

\section{Introduction}

Business administration belongs to an applied major, which cultivates excellent management talents for social management work and provides a talent pool for social development.[1] With the changes of the times, colleges and universities needs to innovate teaching methods in business administration according to the actual situation to promote the development of this major. Based on the foregoing points, it is very important to analyze the existing problems in the teaching of business administration in colleges and universities under the background of new media development, and study how to combine the technique of new media to innovate teaching methods. The combination of new media and business administration can provide convenient auxiliary tools for the development of colleges and universities.[2] On the other hand, talents cultivated in this way can better adapt themselves and make more outstanding contributions in the new media era after entering the society.

\section{Problems in Business Administration Teaching in Colleges}

As for the problems in Business Administration Teaching in colleges, what comes first is inappropriate curricula design. [3] At present, the curricula of business administration in colleges and universities are inappropriate. The major problems are that the curricula are not closely related to students' life and practice, resulting in their low learning initiative and interest in the course content. [4] In addition, it is found that there is a separation between the theoretical curricula and the practical curricula through the author's investigation and research. To be specific, the theoretical knowledge learned by students cannot be well applied to practice. The course content is not updated enough to keep pace with the development of the times, and the corresponding changes in course content should be made according to the actual needs.

The second one is severely inadequate practice. Students majoring in business administration spend most of their time learning theoretical knowledge in school. [5]There are few opportunities for internship or participation in work for training, without which their ability cannot be improved. This traditional learning model is not conducive to the development of students in this major. In other words, it cannot show its higher practical ability as an applied major. The theoretical 
knowledge learned by students cannot be given full play to their real ability in the future work.

The third one is the old-fashioned teaching methods.[6] In the current stage, the teaching form in business administration is mainly that teachers systematically impart the knowledge of textbooks to students on the platform, and students passively receive the knowledge, which results in the low enthusiasm of students for learning. [7]Such monotonous teaching mode tends to make students bored. In addition, this old-fashioned teaching method also inhibits the development of students' creativity and makes them difficult to cope with the rapidly changing management problems. Especially in the new media era, such old-fashioned teaching methods directly lead to the students' low interest in learning and low teaching effect.

\section{Measures to Optimize Business Administration Teaching in the New Media Era}

Firstly, it's to realize real-time teaching. One of the ways to optimize business administration teaching is to teach in real time. Real-time teaching refers to the teaching way that interaction between teachers and students is realized by network and other media. This is a new teaching method emphasizing interactivity, which greatly improves the learning efficiency of students and arouses their enthusiasm for learning. To realize real-time teaching, teachers first need to master new teaching methods, and learn to use network and other auxiliary teaching methods to teach students efficiently. In this process, teachers are advised to constantly improve their teaching ability and improve their knowledge. Second, students are required to do their homework well in advance to achieve the best effect of real-time teaching. The realization of real-time teaching requires the collaboration and cooperation between teachers and students. In real-time teaching, students can not only learn the knowledge of business administration, but also learn to use network and other technical means, which is conducive to professional knowledge learning and broadens their horizon for future management work. Real-time teaching emphasizes both efficiency and effect. Students of business administration need such kind of teaching mode that is closer to practical operation.

Secondly, it's to change the subject in the teaching process. The change of subject in the teaching process is another suggestion for innovative teaching. The aforementioned change of subject refers to the change from teacher to student. The purpose of cultivating talents for business administration is to enable students to have multiple abilities and to better manage the work. During this management work, students as the subject must first be able to do well in "learning". Changing the subject enables students to give full play to their initiative. Teachers are responsible for guiding students to learn to study and manage by themselves, and providing guidance to some difficult problems. Only in this way can students improve their quality and ability. Teachers should make clear their role positioning in teaching and do well in class management and guidance for students. In this way, students can fully display their talents and potential in class, find out their shortcomings and ways to overcome them, and improve the comprehensive quality of students majoring in business administration. Adhering to taking the student as subject can also arouse students' interest and give them a place to display themselves, which is also a kind of heuristic teaching method. Such method helps students develop the ability and awareness of lifelong learning, and provides the foundation for students' long-term development and sustainable classroom teaching.

Thirdly, it's to enrich teaching forms. First of all, the classroom teaching can adopt grouping teaching method. It breaks students up into groups according to their ability or performance levels, and teaches them differently, which conforms to students' individual levels and characteristics. Such method of teaching students in accordance of their aptitude beneficially targets at individual students majoring in business administration. Second, this teaching method renders an opportunity of independent study to the students. To be specific, they can decide learning goals and content under the guidance of teachers, and design classroom activities to gain knowledge and ability. This form has broken the traditional classroom rule that teachers impart knowledge in textbooks to students, but makes students learn independently and promptly report to teachers their learning procedure. For teachers, they only need to master the class situation as a whole. For students majoring in business administration, their learning ability and creativity are cultivated. In addition, to enrich the teaching forms, we also resort to media means, such as pictures on slides and video 
materials, to show the key points to students more intuitively, so that students can feel the learning and management changes brought by the multimedia era.

\section{Reform and Application of New Media in Business Administration}

First is the change of teacher's teaching concept. The integration of "new media" in teaching, such as micro-class and flipped classroom, makes teaching activities more diversified. These forms of teaching activities are most obviously influenced by the network. One can integrate their fragmented time with the aid of network so as to increase efficiency. Meanwhile, such teaching method itself is a challenge to traditional teaching activities, so teachers need to change their previous teaching concepts, with a more open attitude to carry out a series of teaching activities and guide students to participate in learning activities on Internet. In the teaching activities of business administration, students can be organized to actively make a preliminary understanding of successful entrepreneurs' personal stories and enterprise development in Weibo, which may stimulate their interest in participation in personalized teaching activities. This practice pursues people-oriented teaching theory and highlights the principle of teaching according to students' aptitude.

Second is to complement the traditional teaching with "new media" model. Under the environment of network, traditional teaching activities need to complement with the "new media" model. This not only requires teachers to constantly learn and actively change their own concepts in teaching activities, but also requires them to master the mechanism of the "new media" teaching model, as well as a series of means and methods to carry out it. Specifically, first is to promote excellent classes on Internet. It requires to appropriately selecting the course content suitable for online teaching and then promoting it, with emphasis on improving the teaching quality. Second is to encourage more teachers to learn from each other and carry out exchanges and cooperation in various ways, so as to effectively solve the problems in teaching activities and bring into play the value of interactive teaching activities. Third is to guide students to correctly use the network to participate in learning activities and enhance the utilization of network resources. In the teaching activities of the new media, a learning environment focusing on new things studies should be created, which can not only accelerate the understanding of new things, but also innovate the development of new technology. It ensures that the teaching goal can be an influential factor of innovation activities design, and that both teachers and students can make progress in the network environment.

Third is to share and promote education resources. The quality of education resources will greatly affect the teaching work. Therefore, when organizing teaching work, teachers should consciously enhance the quality of education resources, choose a more appropriate network platform to ensure the quality of teaching, so that online teaching can be compared to offline teaching, highlighting the advantages of network teaching. Meanwhile, for different students, education resources should be hierarchical to better meet their learning needs. In this process, what need to do are as follows. First is to share resources in the campus. Different teachers and disciplines should share their advantageous resources to achieve mutual learning and common improvement of the teaching work in the whole university. Second is to share resources nationwide. Specifically, it should build a platform exchanging teaching activities for colleges and universities nationwide to realize shared services and to build a more scientific academic research platform.

\section{Conclusion}

In this paper, the author reflects on the application of the "new media" model through the example of its integration in business administration. At present, the reform of higher education in China is at a critical stage. To strengthen the application of the "new media" model is not only the choice of the times, but also the key for colleges and universities to realize improvement of their own teaching ability. Therefore, teachers should work with students to explore the conduction of teaching work of "new media" model according to the needs of students majoring in business 
administration. Such exploration can lead to valuable advice that helps to realize the further integration of the traditional teaching activities with the "new media", which will eventually improve teaching efficiency and students' learning effects.

\section{Acknowledgement}

In this paper, the research was sponsored by Humanities and Social Sciences of Hubei province and the Project Title: Research on the reform of Internet + and classroom teaching in School of Management (Project No. 16G222). About the author: Associate Professor of Wuhan Business University; Researcher of Internet Business Research Center, Hubei Business College.

\section{References}

[1] Relation performance study. Conway. Journal of Management. 1999

[2] On deepening the school enterprise cooperation, training high skilled talents in Colleges and universities. Shu Peng song, Yuan exhaustion, Xu Qiufa etal. China Education Innovation Herald. 2010

[3] The main factors that influence the cooperation between schools and enterprises in secondary vocational schools and the countermeasures. Wang Huanjie. Jiangsu education. 2010

[4] School enterprise cooperation on the cultivation of vocational ability of vocational school students. Xu Biao, Kong Xiangcheng, Wu Chunfang. Jiangsu education. 2010

[5] Citizens' access to online state legislative documents. Fagan Jody Condit, Fagan Bryan D. Journal of Government Information. 2001

[6] Government documents at the crossroads. Peterson Karrie, Cowbell Elizabeth, Jacobs Jim. American Libraries. 2001

[7] Review. Mon Lorry. Journal of Government Information. 2001 